\title{
THE RED CROSS AND WELFARE SERVICES IN THE HOUSING ESTATES
}

The Vth Red Cross Seminar on Welfare Services, jointly held by the League of Red Cross Societies and the German Red Cross in the Federal Republic of Germany-at the invitation of that Society-met in the vicinity of Bonn, in May 1973, to consider Red Cross Answers to People's Needs, particularly in New Housing Estates. ${ }^{1}$ Delegates from twenty European Societies-welfare offcers, architects, psychologists and others-attended the meeting and continued the preceding Seminar's consideration of the future of Red Cross welfare services. This is a somewhat new field for the Red Cross, one that is continually being enlarged. Mr. Henrik Beer, Secretary General of the League, told the meeting, " we should not be afraid to innovate; we cannot be satisfied with the great role of pioneering which we had in the medical and social fields, but must be in the forefront when it comes to ideas, techniques, methodology and training ". In the field of welfare services, there are a large number of tasks which National Societies should undertake if they want to follow the evolution of the community's needs.

In various ways a town-such as we see it develop ceaselessly, often without any method or plan-poses some difficult problems. It is a living centre whose every activity is necessary to existence; yet those activities should be proportionate to what should continue to be a living community. Urbanization, linked as it has been with industrial development, is a far-reaching phenomenon, and one of the questions to which it gives rise is how welfare services such as those concerned with health and hygiene can adapt to an evolution which is profoundly changing the way of life of almost every European country. Overpopulation, poor housing conditions, dim-

1 The report was published by the League of Red Cross Societies in English, French and Spanish. It summarizes the proceedings of the Seminar and reproduces the papers read. It can be obtained from the League's Social Welfare Unit. 
inishing green spaces, a growing number of accidents, traffic difficulties, air and water pollution, time lost in commuting, loneliness-these are evils from which few city dwellers are entirely freeThe Red Cross should provide new programmes for them. Such programmes were, in fact, the subject of discussion and resolutions at the XXIInd International Conference of the Red Cross.

The Seminar participants, who split into several working groups, were asked to consider four questions:

- Are there new groups in need of help in the various countries?

- What are their main needs?

- What can the Red Cross offer in the different fields?

- Can help be given in the traditional way, or is it necessary to change the forms and methods?

The members of the working groups noted, in the first place, that migrant workers, families who had settled in entirely new surroundings, young married women who went out to work, the young left to their own devices, and the aged, were in special need of assistance. It was therefore necessary for National Societies to be in more immediate touch with the community and to increase their contacts with the members of that community and with the welfare services. Again, they should co-operate more closely with government services and competent private organizations. Specialized training would enable volunteers to bring their work more into line with that of professionals.

In his opening address, Mr. Walter Bargatzky, President of the German Red Cross in the Federal Republic of Germany, described this as "a theme which was scarcely topical twenty years ago, whereas today exactly the opposite is true, in the sense that we may, alas, be tackling it too late". He added that the problem was one which concerned the Red Cross, for in the modern context the Red Cross must not only give first aid or assistance in the event of war or natural disasters. "It also has a social welfare task of equal importance, namely this assistance to the individual in his unseen, unspectacular but often just as painful daily need brought about by illness, poverty, the wheels of civilization, loss of individuality or quite simply through being forgotten." 
The captions of the papers read at the seminar show the wealth of documentary material compiled, but they also show the complexity of the subjects considered: economic growth, mixing of the population and urbanization; new groups of people who need help; new housing estates, new needs, new tasks; socio-psychological aspects; problems of town development from the technical and design points of view. In the ensuing discussions, all delegates voiced the opinion that the most effective role for the Red Cross would be to take action at a sufficiently early stage of new housing estate planning, and to submit detailed proposals to those responsible.

Miss Monique Esnard, representing the League of Red Cross Societies, said that the League wanted to work with those involved and not merely for them. "We hope that-with the help of the introductory reports of our experts--we shall together not only become aware of the new problems facing the world in which we live, but also define-at least in broad outline-a procedure for solving them, with the participation of those involved." And that was the aim pursued by Seminar participants who, like Mr. René Bertrand, Head of the OECD National Account and Growth Studies Division, affirmed that " non-profit-making private bodies will of necessity continue to play an essential role in social welfare matters; for them it is a question of taking the initiative, of making relations with the underprivileged or those suffering from anguish in the modern world more humane. ... There are very extensive openings for possible and even necessary interventions and there can never be enough workers in this sphere of action".

This shows that all were agreed that welfare work should play a more important part in the Red Cross, and that the Red Cross should have a say at the initial stage of planning rather than when it was already too late. It was also considered essential that the Red Cross, when considering those who were to be afforded relief, should bear in mind the constantly renewed plea that those concerned should contribute to bringing about the solutions suggested and the welfare work undertaken.

Members shouldering heavy social responsibilities might find it hard to keep pace with rapid change without some urgent re-thinking about the existing programmes. Mrs. Beate Bremme, Vice- 
President of the German Red Cross in the Federal Republic of Germany, recalled this fact in her closing address:

" The last week has been spent in attempting to find out whether the Red Cross has answers to give to people, particularly in new housing estates. From what I have seen and heard, contact between the delegates was soon established which facilitated good group work, even in this fairly short time. And contacts, as we all know, at times prove most useful. In this respect, it was especially welcome that representatives of the Youth Red Cross participated in this Seminar. In spite of the complexity of the problem and the short time available, some results have been achieved. These could be summarized as a general consensus in favour of the adoption both of a new style of work and of a new approach. Unless these can be found and achieved, the Red Cross Societies in the best humanitarian tradition will not be able to meet the growing demand of a society whose problems are mainly a result of our technical and over-industrialized age.

The suggestions resulting from this week's work could be briefly summarized in two points:

1. Preventive action on the part of Red Cross Societies-so that we are not too late.

2. The realization and acceptance that unless the public is involved at the planning stages and is permitted to influence the decisions, it will not easily accept the help offered.

In other words, we all agree that it has become essential for the Red Cross to re-think its role in order to be adequate in today's fast developing society." 